\title{
The "Ancren Riwle" and Kilburn Priory
}

\section{Author(s): Hope Emily Allen}

Source: The Modern Language Review, Vol. 16, No. 3/4 (Jul. - Oct., 1921), pp. 316-322

Published by: Modern Humanities Research Association

Stable URL: http://www.jstor.org/stable/3713922

Accessed: 20-06-2016 05:45 UTC

Your use of the JSTOR archive indicates your acceptance of the Terms \& Conditions of Use, available at

http://about.jstor.org/terms

JSTOR is a not-for-profit service that helps scholars, researchers, and students discover, use, and build upon a wide range of content in a trusted digital archive. We use information technology and tools to increase productivity and facilitate new forms of scholarship. For more information about JSTOR, please contact support@jstor.org.

Modern Humanities Research Association is collaborating with JSTOR to digitize, preserve and extend access to The Modern Language Review 


\section{MISCELLANEOUS NOTES.}

\section{The 'Ancren Riwle' and Kilburn Priory.}

In the Modern Language Review for October, 1920, the Rev. Vincent MacNabb, O.P., restated his theory that the Ancren Riwle was written by a member of his own order ( $v$. ibid., January, 1916), and attacked my theory that it was written for the three women who were the nucleus of Kilburn Priory (v. Publications of the Modern Language Association of America, October, 1918, and the review by Mr G. G. Coulton in the Modern Language Review of January, 1920). In a short rejoinder I cannot discuss fully the unsatisfactory character of Father MacNabb's account of my hypothesis, and I must hope that anyone who is interested will turn to my original article. I must here, however, comment briefly on a few points.

(1) Father MacNabb writes: 'It is quite true that the Priory of Kilburn was granted to three young women. But there is not any evidence that these three were sisters of one father and of one mother' (p. 406).

To give a complete and accurate statement of the coincidences with the Riwle, Father MacNabb should have admitted that the three young women of Kilburn were (like those of the treatise) inclusae, young, noble, richly endowed, beadswomen, living under a master, and that we have no reason to believe that they were not sisters. Except for one detail (added by Prior Flete of Westminster), we owe our information as to the circumstances of the Kilburn inclusae to charters, in which so familiar a detail as their relationship would hardly be included. Since they went to live together in a secluded hermitage, it would be natural that they should be friends, and perhaps sisters.

(2) Father MacNabb evidently finds it difficult to believe that the Benedictine Abbey of Westminster ever could have supported religious women not formally Benedictine. He cites Gervase of Canterbury's mention of the nuns of Kilburn as 'Moniales Nigrae' without acknowledging that this reference was first brought forward by me (p. 490, n. 23). This indefinite classification was the only mediaeval authority supporting a Benedictine connexion for Kilburn, and the circumstances under which it occurs are such as to make it a very uncertain weapon in argument. Gervase is giving a summary catalogue of all the religious 
houses of England, and it would be very unlikely that in the case of an obscure nunnery of peculiar situation he would give the special investigation necessary to inform him that the cell could not be classed with the patron. Lately I have found a Papal letter of 1391 calling Kilburn Benedictine (Papal letters relating to England, Iv).

Father MacNabb calls the later Augustinian connexion of Kilburn 'not proven' (p. 407), but he neglects to state that (as first pointed out by Park, in his History of Hampstead) the nuns of Kilburn are specifically called Augustinian in a formal appropriation granted them by the Bishop of Rochester in 1377, as well as in a Patent Roll of $26 \mathrm{Ed}$. III (p. 340; see my article pp. 489-92). Moreover, Prior Flete of Westminster calls them 'canonesses,' and no one would know their status better than he, for, according to the arrangements made in 1231 (see my article, p. 495), the Prior of Westminster was to be the official visitor at Kilburn in the absence of the Abbot. Thus we have practically three English official references to the house as Augustinian, against one official foreign one calling it Benedictine. There was every motive for guessing that it was Benedictine, and the three official native authorities which give the unexpected title seem to me almost certainly accurate.

It seems to me quite clear from the records that the trio of women who were put into Kilburn hermitage, c. 1134, were inclusae, unattached to any order (as inclusae often were). I have pointed out cases (pp. 536, n. 96, 539, n. 101) in which Benedictine monasteries took female recluses under their protection, apparently without bringing them into the Benedictine order. For example, in the abbacy of Anselm three women lived as recluses under the protection of Bec, and of these one was the mother of Abbot Crispin of Westminster-whose corrody was one of those granted by St Peter's to the three women at Kilburn.

Since the establishment at Kilburn was perpetuated and enlarged, it was natural that in time it became regularised. I have quoted (p. 491, n. 25) the Papal decree of 1148 urging women of unorganised religious life to attach themselves to the Rule of St Benedict or to that of St Augustine; as well as the union by the Pope in 1244 of various communities of hermits under the Rule of St Augustine. Doubtless there were other efforts at various times to regularise indefinite religious organisations, and Father MacNabb (p. 407) has mentioned one when he notes that 'St Dominic had been commissioned by the Pope to gather the anchoresses of Rome into one Convent under one Rule.' Various considerations probably dictated the choice of one of the two great rules rather than another, but Dr Frere points out (as I note, p. 492) that the Augustinian Rule was 
an indefinite one which could be assumed without altering local custom: ' The Rule,' he remarks (op. cit., p. 213), 'as compiled out of St Augustine's letter, does not enter into details nor prescribe minutiae, as does the Rule of St Benedict, which is a real Rule.' Perhaps because it did not change their regimen, it was adopted by many old houses. When Kilburn Priory, the cell of a Benedictine house, became regularised, it would certainly be natural that it should have come into the order of its patron, and the fact that it did not may hint at some unusually well-established local custom, which it was desirable to preserve, though it could not be reconciled with the Benedictine Rule. If the Ancren Riwle had been written for this house, we can imagine that when Kilburn became regularised it would choose the rule which would allow it to continue the manner of life laid down in the treatise, and this would be possible only under the Rule of St Augustine. A powerful motive would thus be given for rejecting the rule of the patron abbey, and one which we can imagine that Westminster would honour.

I do not see that it is in the least 'fatal to my thesis' that we do not know when the regularising influence reached Kilburn and made it Augustinian. Father MacNabb's opinion that it is seems due to the misinterpretation which he gives to the following words of mine: "The Rev. Vincent MacNabb...has made the interesting discovery that the Rule of St Augustine was used in the Ancren Riwle' (p. 492). This apparently gives rise to the following, in his second article: 'Miss Allen agrees with us in thinking that the Ancren Riwle is quite definitely Augustinian' (p. 407). He believes evidently therefore that the treatise can only be attached to a house certainly Augustinian from its foundation.

I do not for a moment believe that the use of the Augustinian Rule in the treatise made the Riwle 'Augustinian'-if by that is meant written for or by persons of that order. Father MacNabb neglects to note (what is highly significant for the dating of the work) that I have pointed out the quotation verbatim of a considerable section of the Carthusian Customs, as well as unmistakable reminiscences of the apology for the Cluniacs against the Cistercians made by Peter the Venerable (v. pp. 488 f., 515-33). If the Augustinian influence on the treatise makes it Augustinian, then the Carthusian influence makes it Carthusian, and the Cluniac influence makes it Cluniac. The truth is that we find reflected in the Ancren Riwle an unsectarian, eclectic spirit akin to that which, in the same decade in which Kilburn was founded, produced the Gilbertine order. The Gilbertine men were Augustinian, the women Benedictine, and the lay-brothers Cistercian. The middle of the twelfth century was 
a rare age, in which the sectarian distinctions insisted on by Father $\mathrm{MacNabb}$ were sometimes ignored. The author of the Riwle shows a peculiarly strong sympathy with the party which ignored them-the older Benedictines, the patrons of Kilburn.

(3) Father MacNabb writes: 'But the circumstances of the three sisters which is supposed to be fatal to the Dominican authorship of the Rule is especially detailed in Codex N (Morton's text). Now it is precisely this text which gives the paragraph of the lay-brother's office of Pater Nosters....Miss Allen dismisses this passage as an interpolation of $\mathrm{N}$; not as an omission by the other MSS. The only grounds we can discover for Miss Allen's canon of rejection is that it is demanded by her theory' (p. 407).

The grounds for my rejection at this point can be found discussed in my article pp. $539-41$.

(4) Father MacNabb, as in his first article, brings forward (p. 407) to support his theory of Dominican authorship the mention of friars in MS. B and the French (which includes some of the elaborate new material found in B). He seems hardly to realise where this lands his argument. MS. B has substituted for the description of the circumstances of the three sisters (entirely absent here) an extended description of 'twenty recluses and more,' to whom the work is addressed in this copy. How can Father MacNabb accept from $\mathrm{N}$ the passages as to the lay-brothers and the three sisters, and from B, as if equally part of the original text, the passages as to friars-at the same time rejecting from the latter manuscript the passage as to the twenty recluses as well as (inevitably) many others?

In his strictures on my article just quoted he has implied that no evidence is sufficient to justify a critic in accepting some and rejecting other variations of a single manuscript, yet he has made his own comprehensive discrimination entirely without explanation. He does not mention the fact that some of the new material introduced by $B$ is indisputably interpolation, and that probably all of it is. He also neglects to note that I have pointed out (pp. $492 \mathrm{ff}$.) that this matter, which Mr Macaulay shows must have been added about 1230, can be connected with the reorganisation of Kilburn which took place under a Papal Commission about 1231. It may be noted, as a highly significant detail, that Mr Macaulay had thought it 'interesting to note' that the new material specially gives directions for a bishop's visit, and the most important innovation brought about in 1231 at Kilburn was that henceforth the Bishop of London was to have the right of visitation. 
(5) Father MacNabb concludes his account of my hypothesis as follows :

'We are quite willing to admit, as a mere possibility, that the Riwle was written for Kilburn; provided that it is agreed that its author was a Friar-Preacher' (p. 407). How can this be? The Kilburn connexion of the treatise, if it exists at all, is only valid during the years immediately following 1134 , when three young women were inhabiting the hermitage whose circumstances strikingly correspond with those described in the Ancren Riwle. This was, of course, nearly a century before the beginning of the Dominican order.

In conclusion Father MacNabb adds what he believes to be four new items of evidence for his hypothesis.

(1) What he calls (p. 408) a "very definite form of saying the Officium Beatae Mariae Virginis' appears to me a custom likely to be initiated by anyone so fond of using the Pater Noster and Ave Maria as was the author of the Ancren Riwle. A miracle dated at 1257 is said to attach it to the Dominicans exclusively (see H. Leclercq, Histoire des Conciles, Paris, 1913, v, 2nd part, App. IV, p. 1747, n. 10), but Durandus in 1286 seems to make it a general usage (see J. J. Bourassi, Summa Aurea De Laudibus B. V. M., ed. Migne, Paris, 1862, IV, p. 267). Father Thurston has shown that in the case of the Rosary a miracle has appeared to give the Dominicans an exclusive claim to a custom that was rooted long before their time (see the Month, 1900-1 passim). 'The miracle attaching the present custom exclusively to the Dominican order may not be conclusive proof of origin, and so natural a procedure may have been sporadically practised during the twelfth century, as was the Rosary. In any case, since Father MacNabb gives no references for his assertions at this point, his evidence cannot be taken very seriously.

(2) The evidence drawn from the Oxford Dictionary again appears to be of the sort which might be illustrative, but cannot be conclusive.

(3) Father MacNabb quotes at length from the Riwle to show 'the frequent use of the Ave Maria as a prayer,' 'which makes it impossible to assign the Ancren Riwle to a date earlier than c. 1230' (p. 408). He gives no authorities for his categorical statement, and neglects to note that I have taken up this subject at some length (pp. 534-5), and cited authorities proving that ' among ascetics this custom goes back very far.' For example I note that 'Aves make part of the devotion of the "Five Psalms of the Virgin," first pointed out in the treatise by Father MacNabb, and this devotion can be carried back to the middle of the 12th century with the Aves as it is found in the Riwle (the form used by 
Jordan of Saxony, noted by Father MacNabb, does not contain the Aves).' At this, and numerous other points, I convict Father MacNabb's first article of incomplete information, but he passes over these items in his second without comment, and still (p. 407) speaks of his ' multiple series of identifications and triangulations,' his 'almost countless verification' (p. 408).

(4) 'A further identification of the Ancren Riwle with a Dominican writer is to be found in MS. B... and in the French....Fr. Thurston, S.J., was the first to recognise in this passage the earliest form of the Rosary. But to deal sufficiently with this most interesting point would need a further article' (p. 409).

Considering the results of Father Thurston's researches on the origin of the Rosary ( $v$. supra), it is not strange that Father MacNabb leaves this point undeveloped.

To recapitulate for controversial purposes has been the unfortunate enterprise of the present paper, but it will not have been useless if it succeeds in enlisting new interest in the theory of the connexion of the Ancren Riwle with Kilburrt Priory. This theory derives its material from legal documents, and, if accepted, would anchor the treatise to a date, a place, and a group, with consequent great effect on the study of history, of literature, and of liturgy. Verification sufficient to convince the doubter may come from any quarter, and in view of the wide implications it is desirable that the hypothesis should be given the widest possible publicity, in the hope of gaining the widest possible cooperation.

Since writing the above I have come across Dr Joseph Hall's Selections from Early Middle English (Oxford, 1920) in which he makes a conjecture as to the origin of the Ancren Riwle and the connected pieces which is somewhat similar to my own. He believes that these works are 'the product of the Gilbertine movernent' (p. 505), and even goes so far as to conjecture (p. 376) that they were all composed by St Gilbert himself, who, according to his contemporary biographer, was a prolific writer.

In an article in the Romanic Review, April-June, 1918 (pp. 154193), and in my article on the Ancren Riwle, I have expressed opinions somewhat similar to the first and more general part of Dr Hall's theory. In the latter (p. 536) I wrote as follows: 'We have evidence from the historical side of a religious revival in England during the reign of Stephen, of which the spirit expressed in the mystical English works earlier grouped together is exactly characteristic. Passages quoted in

M. L. R. XVI. 
my earlier article in which St Aelred describes the devotion of Gilbertine nuns should be put side by side with the "Katherine group," or the ecstatic rhapsodies, for example, to show how likely it is that these pieces...should have emanated from the same environment....It may be that some of the English mystical works written in Southern speech originated in the Gilbertine houses of the North Midlands. Perhaps they were written by Gilbert himself, who, as we are told by his contemporary biographer, "wrote books."

In making the statement just quoted I did not mean to imply that the Ancren Riwle could have been written by St Gilbert, though I believe that other works of the group may have been. I believe that the author of the Riwle wrote at a time of many strong religious influences, one of which was the Gilbertine. He was sensitive to all, but he did not give the zeal of a partisan to any. He shows, however, a sympathy not untouched with heat for the liberal-Benedictine movement of his daywhich was the cause of Westminster, the patron of Kilburn. He was probably a congenial friend of St Gilbert and of St Aelred, but he certainly found his closest affiliation with Peter the Venerable, the apologist for the older Benedictines. In the case of the other works of the group there is nothing to show a similar state of mind in their author. There is nothing to show that he was detached from organisations, or had sympathy for one rather than another. Therefore, though they may have been composed by members of any of the several orders which were then in an active state of germination,--by St Gilbert, or by St Aelred,-it would be difficult to fix their authorship. It would be equally difficult to fix the general circumstances of their origin, for none of them furnishes the explicit personal details found in the Ancren Riwle. Those details of the treatise offer an opportunity for definite confirmation of origin probably unexampled in mediaeval literary history, and they are all unanimous in supporting the connexion with Kilburn.

LoNDON.

Hope Emily Allen.

\section{Chaucer's Triple Roundel, 'Merciles Beaute.'}

In the Modern Language Review, Vol. I, p. 36, Prof. J. L. Lowe relates the Chaucerian triple roundel Merciles Beaute to three poems of Deschamps. The réponse of the Duc de Berry to the authors of the Cent Ballades ${ }^{1}$ has as its first line:

Puiz qu'a Amours suis si gras eschapé

1 Ed. by Gaston Raynaud : Société des Anciens Textes Français: Paris, 1905, p. 213. 